\title{
Community Partnership Program (PKM) Research Statistics for Teachers in NU Plus Vocational School, Sidoarjo
}

\author{
Author \\ Edy Widayat, Ardianik, Sucipto \\ Correspondence \\ Universitas Dr. Soetomo Surabaya \\ edy.widayat@unitomo.ac.id, ardianik@unitomo.ac.id, sucipto@unitomo.ac.id
}

\begin{abstract}
The NU PLUS vocational school (SMK) located in Sidoarjo Regency as a forum for nation generation, always applies various methods and development of learning media to answer the demands of the era to produce highquality human resources, the problem facing this school is that the ability of teachers is still lacking in analyzing research data using statistical tests. Therefore, it is necessary to increase human resources concerning research through data analysis training. One way to help teach teachers in conducting research is to provide training in research data analysis using SPSS software. SPSS software is a software that can help process research data making it easier for researchers to analyze the data. This training aims to solve the problems faced by Sidoarjo Vocational High School teachers as partners, by providing training and mentoring methods of data analysis which include: 1) Methods of data analysis using descriptive statistics; 2) Methods of Quantitative data analysis using parametric statistics; 3) Qualitative Data Analysis Method using non-parametric statistics; 4) Research Methods, Classroom Action Research. The training design above is expected to improve some of the abilities and skills of the Sidoarjo Vocational High School teachers, including the following: 1) Processing research data using descriptive statistics; 2) Quantitative data processing using parametric statistics; 3) Processing of qualitative data using non-parametric statistics; 4) Mastering Research methods with Quantitative and Qualitative Approaches; 5) Able to carry out Classroom Action Research. The expected target of the community service activities in Sidoarjo Plus Vocational School includes: 1) Increased understanding, ability, and skills in analyzing data using descriptive statistics; 2) Increasing understanding, ability and skills in analyzing quantitative data by utilizing various kinds of parametric statistical tests that are tailored to the problem; 3) Improve understanding, ability and skills in analyzing qualitative data by utilizing various kinds of non-parametric statistical tests that are tailored to the problem; 4) Training manual; 5) Certificates and posters; 6) Scientific Publication in the Journal.
\end{abstract}

Keywords: descriptive statistics, non-parametric statistics, parametric statistics

Received: 13 October 2018. Accepted: 05 November 2018

\section{Introduction}

Referring to Indonesian law No. 20 in 2003 concerning the national education system, Indonesian law No. 14 in 2005 concerning teachers and lecturers and government regulations No. 19 in 2005 concerning the national standard of education mandates that teachers must have academic qualifications, competencies, educator certificates, physically and mentally healthy, and can realize national education goals. The minimum academic qualification of the teacher is S1 / D-IV as evidenced by a diploma by the type, level, and formal education unit at the assignment. The teacher has a position as a professional at the level of primary education, secondary education, and early childhood education, in the formal education pathway that is appointed following the laws and regulations. An educator certificate proves recognition of the position of the teacher as a professional teacher. Furthermore, law number 14 in the year of 2005 concerning teachers, defines that a professional is a job or activity carried out by a person and becomes a source of income for life that requires expertise, skills, or skills that meet certain quality standards or norms and requires professional education. It is hoped that the teacher as a professional can function to improve the dignity and role of the teacher as an agent of learning and serves to improve the quality of national education.

The ability to research for teachers is essential because it is a professional demand. For career 
development and to improve education qualifications, teachers are advised to study to a higher level of education, besides that they must fulfill the research requirements included in writing scientific work. This requirement is often an obstacle to increasing the rank level for teachers or demands for completion of a thesis or dissertation for further studies (S2-S3) that require research activities.

Data analysis is the core knowledge and skills needed in each time doing a research. If a teacher does not master the knowledge and skills of analyzing the data and research findings, we can be sure when conducting research, and the teachers will experience significant difficulties. This is often an obstacle for teachers to carry out research considering the low ability and interest in research among teachers.

In addition to be a condition for career development, research is also a means for developing a teacher. The teacher has a lot of potentials to be more optimally developed by research. This is possible because the teacher is supported by many conditions that strengthen opportunities for the development of the ability to teach and research. First, teachers always interact with science which can be used as the material for research. Second, teachers always interact with students in classroom learning that can be a source of research. Third, teachers often interact with the world of education and various dynamic policies that always demand to think, issue innovative ideas. Fourth, there are many opportunities for research competitions, both held by the Education Office and the Ministry of Religion as the institution that shelves them. Fifth, mass media provides many educational rubrics that allow teachers to express innovative ideas both in teaching and researching.

In general, several obstacles can be found so that the level of participation in research among teachers is low. First, low interest in reading and researching. Research activities are not released from reading activities. So far, teachers are more preoccupied with teaching activities in the classroom, so the obligation to read for their development becomes not optimum. Second, the limited availability of reading materials is another obstacle. Third, lack of confidence and lack of experience in researching. Fourth, the teacher does not understand the scientific provisions to be able to be skilled in research. Fifth, the low motivation to research, this is because the teachers feel less mastered in the science of research, also the lack of ability to analyze data following the type of research approach. Constraints above also occur on teachers at SMK Plus NU in Sidoarjo, considering the number of teachers with 37 people consisting teachers with master degree (4), under graduate (33), and administrative (8).

Based on these conditions, the lecturers of the Mathematics and Technology Education study program at the Faculty of Teacher Training and Education at Dr. Soetomo felt that they needed to carry out community service in the form of a Statistical Community Partnership Program for Research Teachers at NU Plus Vocational Schools in Sidoarjo Regency. The scope of debriefing was directed at data analysis in the writing of scientific papers in the form of Classroom Action Research (PTK), thesis and dissertation for advanced studies, both data analysis using descriptive statistics, quantitative data analysis using Parametric statistics, and qualitative data analysis using nonparametric statistics to improve the quality of research, remembering the type needed by the teacher to take advantage of these opportunities.

\section{Partner Problems}

Referring to the analysis of the situation, the priority issue agreed to be resolved during the implementation of the community service program at NU Plus Vocational School in Sidoarjo Regency is to improve the abilities and skills of teachers in choosing statistical methods and analyzing data using descriptive statistics, parametric statistics and non-statistics parametric through training and mentoring with the help of SPSS version 19 software, making it easier and enabling teachers to conduct a classroom action research, qualitative research and quantitative research which in time can be used for promotion and used in completing a thesis or dissertation if the teacher is concerned to attend in higher education.

\section{Implementation Method}

This activity was carried out in two stages, namely the first stage is an explanation of the concept of research approach, types of research, research design, method of determining 
respondents, data collection methods, population and samples, research instruments, validity and reliability, data normality test, homogeneity test variance, various methods of data analysis using descriptive statistics, parametric and nonparametric statistics, hypothesis testing. The second stage includes seven activities, namely training and mentoring: 1) analyzing the data using descriptive statistics in accordance with the availability of data; 2) practicing data analysis using descriptive statistics in accordance with available data; 3) use of quantitative data analysis methods using parametric statistics; 4) practicing quantitative data analysis methods using parametric statistics with various characteristics; 5) use of quantitative data analysis methods using non parametric statistics; 6) practicing quantitative data analysis methods using non-parametric statistics with various characteristics; and 7) classroom action research training (CAR)

The activities covering the two stages above are followed by all the teachers, amounting to approximately 30 people located in the computer laboratory Vocational School Plus at Sidoarjo, conducted every Friday and Saturday from July 25 to August 31, 2018 based on the agreement of the partners, considering the free time for teachers on Friday and Saturday, Friday starting at 13.00 until 16.00 , and Saturday starting at 08.00 to 14.00 , all computers have been installed with the software version of SPSS 19 and was carried out thoroughly, meaning teachers trainees really have been able to choose data analysis methods that are in accordance with the characteristics of existing data, are able to use data analysis methods, and are able to develop various types of data analysis methods, so that teachers were no longer experience difficulties in carrying out research because they already have the ability to analyze data according to the type and characteristics of data and research design. Thus, it is expected that the teacher's ability to research will increase.

\section{Activity Results}

Community service program this obtain results including the following:

1. Improving the ability and skills in selecting and using methods of data analysis from various cases given during mentoring program. The teacher also looks very enthusiastic in choosing the statistical tests relevant with the case given.

2. Improve the ability and skills in analyzing data by using descriptive statistics, parametric statistics, and nonparametric statistics from various cases given; this can be seen by showing the results of the output of data analysis using SPSS software and being able to interpret it well.

3. Mentoring in making classroom action research based on the problems faced by each trainee while teaching in class.

The Training Program for NU Vocational High School Teacher Statistics in Sidoarjo Regency was held from July 25 to August 31, 2018, which was held in partner computer laboratories with good results. This is evidence, impressions and remarks from all the teachers who attended the training and mentoring program during the implementation of community partnership program.

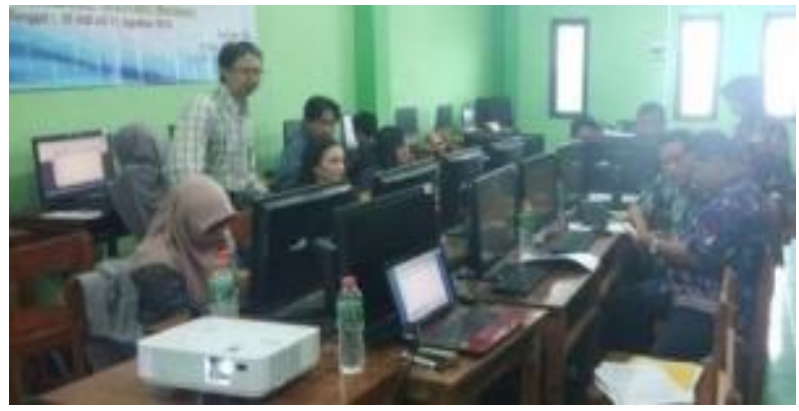

Figure 1 Training Situation in the Computer Laboratory Room

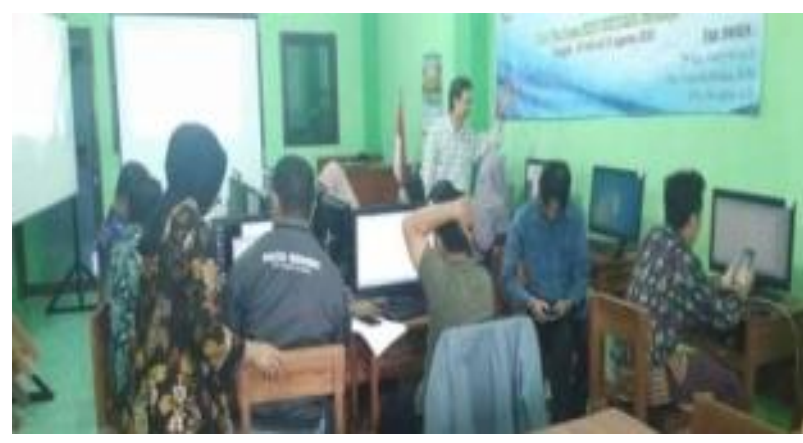

Figure 2 Assistance in training that is being carried out by resource persons

\section{Conclusion}

From the results of the training and coaching that have been conducted, it can be concluded that there are significant differences in terms of improving the abilities and skills of teachers in choosing and using data analysis methods that are 
in accordance with the cases, able to analyze data using descriptive statistics, non-parametric statistics and parametric statistics, as well as being able to interpret the results of the output using SPSS software, able to make classroom action research based on the problems faced by each trainee while teaching in class after being given a training.

The results showed that teachers benefit from the training and clinic given by the team of instructors were rated satisfactory, as seen from a series of activities this community service program has a success rate of $90 \%$. This is shown from almost all outcomes achieved and succeeded in teachers of the NU Vocational High School in Sidoarjo Regency. Good collaboration between partners and service team is the primary capital in the success of this activity. Therefore, it is necessary to increase the trust and commitment of each party so that goals can be achieved with satisfactory results.

\section{Reference}

Algifari, 2016. Statistik Deskriptif untuk Penelitian,.Penerbit : Raja Grafindo Persada

Arikunto Suharsimi, 2015. Penelitian Tindakan Kelas (Edisi Revisi), Penerbit: Bumi Aksara

Arikunto Suharsimi, 2015. Metode Analisis data kuantitatif dan kualitatif. Penerbit: Bumi Aksara

Buku panduan Penulisan Skripsi, Tesis dan PTK Fakultas Keguruan dan Ilmu Pendidikan Universitas Dr. Soetomo Surabaya

Bungin Burhan, 2018. Metodologi Penelitian Kuantitatif, Edisi Kedua, Penerbi t: Prenada Media Group

Djarwanto, 2013; Mengenal Beberapa Uji Statistik dalam Penelitian, Penerbit: Liberty, Yogyakarta

Ghozali Imam, 2015. Statistik Non Parametrik, Teori dan Aplikasi dengan Program IBM SPSS 23. Edisi Kedua, Penerbit: Universitas Diponegoro Semarang

Ghozali Imam, 2015. Statistik Parametrik, Teori dan Aplikasi dengan Program IBM SPSS 23. Edisi Kedua, Penerbit: Universitas Diponegoro Semarang

Sertifikasi Guru Dalam Jabatan. 2010. Direktorat Jendral Pendidikan Tinggi kementerian Pendidikan Nasional
Wahyono Teguh. 2015. Analisis Data Statistik dengan SPSS 21. PT. Gramedia Jakarta 